\title{
AUTORADIOGRAPHIC LOCALIZATION OF MUSCARINIC CHOLINERGIC RECEPTORS IN RAT BRAINSTEM ${ }^{1}$
}

\author{
JAMES K. WAMSLEY, MARY S. LEWIS, W. SCOTT YOUNG, III, AND MICHAEL J. KUHAR \\ Departments of Pharmacology and Psychiatry, The Johns Hopkins University, School of Medicine, Baltimore, Maryland 21205
}

\begin{abstract}
We have localized muscarinic cholinergic receptors in the rat brainstem by a light microscopic autoradiographic method. Initially, we examined the kinetics and specificity of the binding of radiolabeled quinuclidinyl benzilate $\left(\left[{ }^{3} \mathrm{H}\right] \mathrm{QNB}\right)$ in slide-mounted, frozen tissue sections to determine that we were labeling the muscarinic cholinergic receptors as they had been described previously in biochemical pharmacological studies. Subsequently, using optimal binding parameters to obtain high specific to nonspecific ratios, we labeled tissue sections and generated autoradiograms by the apposition of emulsioncoated coverslips. We found high concentrations of autoradiographic grains associated with many nuclei in the brainstem including the superior colliculus, nuclei of the lateral lemniscus, pontine nucleus, parabrachial nucleus, trigeminal nerve nucleus (V), the tegmental nuclei, nucleus of the facial nerve (VII), the locus coeruleus, the medial vestibular nucleus, cochlear nucleus, nucleus of the tractus solitarius, and nucleus of the hypoglossal nerve (XII). We conclude that muscarinic cholinergic effects of acetylcholine are important in the normal function of both the sensory and motor systems. We speculate on the possible mechanisms of action of certain cholinergic agents, such as the mechanism of anticholinergic compounds when used to treat motion sickness or anticholinesterase poisoning.
\end{abstract}

Acetylcholine is widely accepted as a neurotransmitter in the mammalian brain. A variety of electrophysiological, behavioral, and biochemical studies show that its involvement is widespread in the central nervous system (for review, see Phillis, 1970; Hebb, 1970, 1972; DeFeudis, 1974; Krnjevic, 1969, 1974; Fonnum, 1975). The localization of cholinergic neurons was attempted by the histochemical study of acetylcholinesterase (AChE) (Shute and Lewis, 1963, 1965, 1967; Lewis and Shute, 1967). Based on this, various lesion studies sometimes confirmed the existence of cholinergic pathways in the brain (Lewis et al., 1967; McGeer et al., 1969; Kuhar et al., 1973, 1975). Recently, more specific studies on the immunohistochemical localization of choline acetyltransferase indicate the possibility of mapping the brain for cholinergic neurons (McGeer et al., 1974; Eng et al., 1974; Kimura et al., 1980). A more complete description of cholinergic systems would require a knowledge of the pharmacology and location of cholinergic receptors. Thus, biochemical and cytochemical studies of receptors have been performed. For example, radiolabeled quinuclidinyl benzilate $\left(\left[{ }^{3} \mathrm{H}\right] \mathrm{QNB}\right)$ has been used in our labo-

\footnotetext{
'We wish to thank Mrs. Naomi Taylor for technical assistance and Ms. Darlene Weimer and Mrs. Jane Wamsley for secretarial assistance. This work was supported by Grant MH25951 and Research Scientist Development Type II Award MH00053 (M. J. K.) and National Institutes of Health Postdoctoral Fellowships HD05739 (J. K. W.) and MH07624 (W. S. Y.).
}

ratory for the light microscopic localization of muscarinic cholinergic receptors in rat forebrain (Kuhar and Yamamura, 1974, 1975, 1976). The present report involves muscarinic cholinergic receptor mapping in the hindbrain.

\section{Materials and Methods}

The overall light microscopic autoradiographic technique utilized involved receptor binding in vitro in slidemounted tissue sections and the generation of autoradiograms by the apposition of emulsion-coated coverslips (Young and Kuhar, 1979). Before autoradiographic studies were performed, extensive biochemical studies on the slide-mounted tissue sections were carried out to determine optimal receptor binding conditions.

Determination of optimal binding conditions. Five male, Sprague-Dawley rats (150 to $200 \mathrm{mg}$ ) were perfused intracardially with ice cold $0.1 \%$ formaldehyde in phosphate-buffered saline (PBS) at $\mathrm{pH}$ 7.4. The brains of the animals were quickly removed, sliced into approximately 5 -mm sections, mounted with O.C.T. Compound (LabTek Products, Naperville, IL) onto brass chucks, and frozen by slow immersion into liquid nitrogen. Following a warming period to $-20^{\circ} \mathrm{C}, 10-\mu \mathrm{m}$ coronal sections were cut from frontal and parietal lobe areas (which included corpus striatum) on a Harris cryostat (N. Billerica, MA) and the sections were thaw-mounted on chrome-alum/ gelatin-coated "subbed" slides and stored at $-15^{\circ} \mathrm{C}$. Binding characteristics were examined by incubating 
slide-mounted tissue sections (one group of sections for each time interval or concentration) in Coplin jars containing $\left[{ }^{3} \mathrm{H}\right] \mathrm{QNB}$ in PBS. Another group of sections was incubated using the same conditions, but with $1 \mu \mathrm{M}$ atropine added to the $\left[{ }^{3} \mathrm{H}\right] \mathrm{QNB}$-buffered solution. Following the incubation period, the slides were rinsed in Coplin jars containing buffer alone, and then the labeled tissue sections were wiped from the slides with glass microfiber GF/B filter discs (Whatman, England). These discs were placed in individual scintillation vials which contained $10 \mathrm{ml}$ of Formula-947 (New England Nuclear, Boston, MA) and the vials were stored at $4^{\circ} \mathrm{C}$ overnight. Each vial then was counted in a liquid scintillation counter and the total binding (counts from tissue incubated in [ $\left.{ }^{3} \mathrm{H}\right] \mathrm{QNB}$ and buffer) versus nonspecific binding (counts from tissue incubated in [ $\left.{ }^{3} \mathrm{H}\right] \mathrm{QNB}+$ buffer + atropine) were compared.

Autoradiographic procedure. For autoradiography, the optimal binding parameters determined from the dissociation, association, and saturation curves were employed to label $6-\mu \mathrm{m}$ sections of tissue from various regions of the brainstem. Thus, sections from the brains of four animals were incubated for $2 \mathrm{hr}$ at room temperature in $1 \mathrm{nM}\left[{ }^{3} \mathrm{H}\right] \mathrm{QNB}$ followed by two 5 -min rinses in ice cold PBS. These conditions resulted in a $80 \%$ occupancy of receptors by $\left[{ }^{3} \mathrm{H}\right] \mathrm{QNB}$. The slide-mounted tissue sections were dried on a cold plate by a stream of filtered air passed first through a trap cooled by a dry ice/acetone mixture, followed by passage through another trap containing Drierite (W. A. Hammond Co., Xenia, $\mathrm{OH}$ ). The drying process was complete in about $30 \mathrm{sec}$. The slides then were stored at $4^{\circ} \mathrm{C}$ in boxes containing Drierite until coverslips were applied.

The coverslips employed in these studies were $25-\mathrm{mm}$ $\times 77$-mm thin flexible coverslips (No. 0, Corning Glass Works, Corning, NY) which we had coated with a uniform layer of photographic emulsion (NTB-3, Kodak, Rochester, NY) by dipping the coverslip into a Coplin jar containing the emulsion (diluted $1: 1$ with $\mathrm{H}_{2} \mathrm{O}$ ) and allowing it to dry. Under safe light conditions, the dry emulsion-coated coverslip was glued to the frosted end of the slide and clamped down onto the tissue-containing end of the slide with a piece of Teflon and a binder clip. These assemblies were stored for 2 weeks at $4^{\circ} \mathrm{C}$ in lighttight boxes containing desiccant. Following this exposure period, the Teflon and binder clip were removed and the coverslip was bent back (slightly) away from the tissuecontaining end of the slide and maintained in that position by insertion of a small piece of plastic between the coverslip and slide. The autoradiographic image then was developed on the coverslip by immersing the assemblies in developer and fixer. Next, the tissues were stained with pyronin $Y$ and dried on a slide warmer for several hours, and then the coverslip was re-apposed over the tissue and mounted with Permount (Fisher Scientific Co., Fair Lawn, NJ).

Low magnification photography and examination of the tissue and autoradiograms were accomplished using an Olympus JM microscope equipped with a light base suitable for bright-field and dark-field illumination. Higher magnifications of defined areas were examined using an Ortholux II (Leitz, Wistar, Germany) microscope equipped with a Hinsch-Goldman box (Bunton

Instrument Co., Rockville, MD). Grain counts were performed on the coverslip over tissue sections under brightfield illumination using a $\times 100$ oil immersion objective lens on a standard Zeiss (West Germany) microscope and counting grains within the squares of a grid-containing eyepiece. Brainstem levels were determined by comparison with sections from diagrams by Palkovits and Jacobowitz (1974) and Konig and Klippel (1963).

$\left[{ }^{3} \mathrm{H}\right]$ Quinuclidinyl benzilate $(l$ isomer) was purchased from the Amersham/Searle Corp. (Arlington Heights, IL) with a specific activity of $33 \mathrm{Ci} / \mathrm{mmol}$. Scopolamine, tubocurare, and hexamethonium were purchased from Sigma Chemical Co. (St. Louis, MO). Atropine sulfate was obtained from J. T. Baker Chemical Co. (Phillipsburg, NJ) and pilocarpine was obtained from Burroughs Wellcome \& Co. (Tuckahoe, NY).

\section{Results}

Biochemical sludies. Excellent results have been acquired using $\left[{ }^{3} \mathrm{H}\right] \mathrm{QNB}$ to label muscarinic cholinergic receptors as outlined in this study. We were able to obtain specific to nonspecific ratios as high as 79:1 when we were studying the binding of $\left[{ }^{3} \mathrm{H}\right] \mathrm{QNB}$ to our tissue sections and as high as 99:1 when we counted grains over specific nuclei (Table I). Figure 1 demonstrates the dissociation of $\left[{ }^{3} \mathrm{H}\right] \mathrm{QNB}$ binding following a $1-\mathrm{hr}$ incubation in $1.0 \mathrm{nM}\left[{ }^{3} \mathrm{H}\right] \mathrm{QNB}$. Note the very rapid loss of nonspecific binding and the maintained high level of specific. binding throughout the entire rinsing procedure. Figure 2 depicts the association rate of $\left[{ }^{3} \mathrm{H}\right] \mathrm{QNB}$ with its receptor using various incubation times in a $1.0 \mathrm{~nm}$ concentration of [ $\left.{ }^{3} \mathrm{H}\right] \mathrm{QNB}$ followed by two 5-min rinses. Equilibrium is reached after 120 min of incubation at room temperature. Figure 3 shows the rate of saturation of the

TABLE I

Examples of the number of autoradiographic grains over selected nuclei

\begin{tabular}{ccc} 
& Specific & Specific: \\
Nucleus & Graius/ & Nonspecific \\
& $529 \mu \mathrm{m}^{2}$ & Ratio \\
& Tissue" & \\
\hline
\end{tabular}

Very high

Nucleus parabrachialis dorsalis

Nucleus ambiguus

Nucleus originis nervi facialis

18.81

14.54

17.22

High

Nucleus tractus solitarius

Nucleus cuneatus lateralis

External layer of inferior colliculus

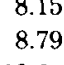

12.6

$18: 1$

$12: 1$

\section{Intermediate}

Nucleus reticularis parvocellularis

Nucleus olivaris inferioris

4.69

4.73

5.36

$12: 1$

Nucleus cuneatus

Nucleus reticularis pontis caudalis

Nucleus reticularis gigantocellularis

2.08

"Nonspecific grain densities (on sections which were incubated in $\left[{ }^{3} \mathrm{H}\right] \mathrm{QNB}$ and atropine) varied from 1 to 10 per $529 \mu \mathrm{m}^{2}$ of tissue and were subtracted from the number of grains counted on sections which had been incubated in [ $\left.{ }^{3} \mathrm{H}\right] \mathrm{QNB}$ alone. 


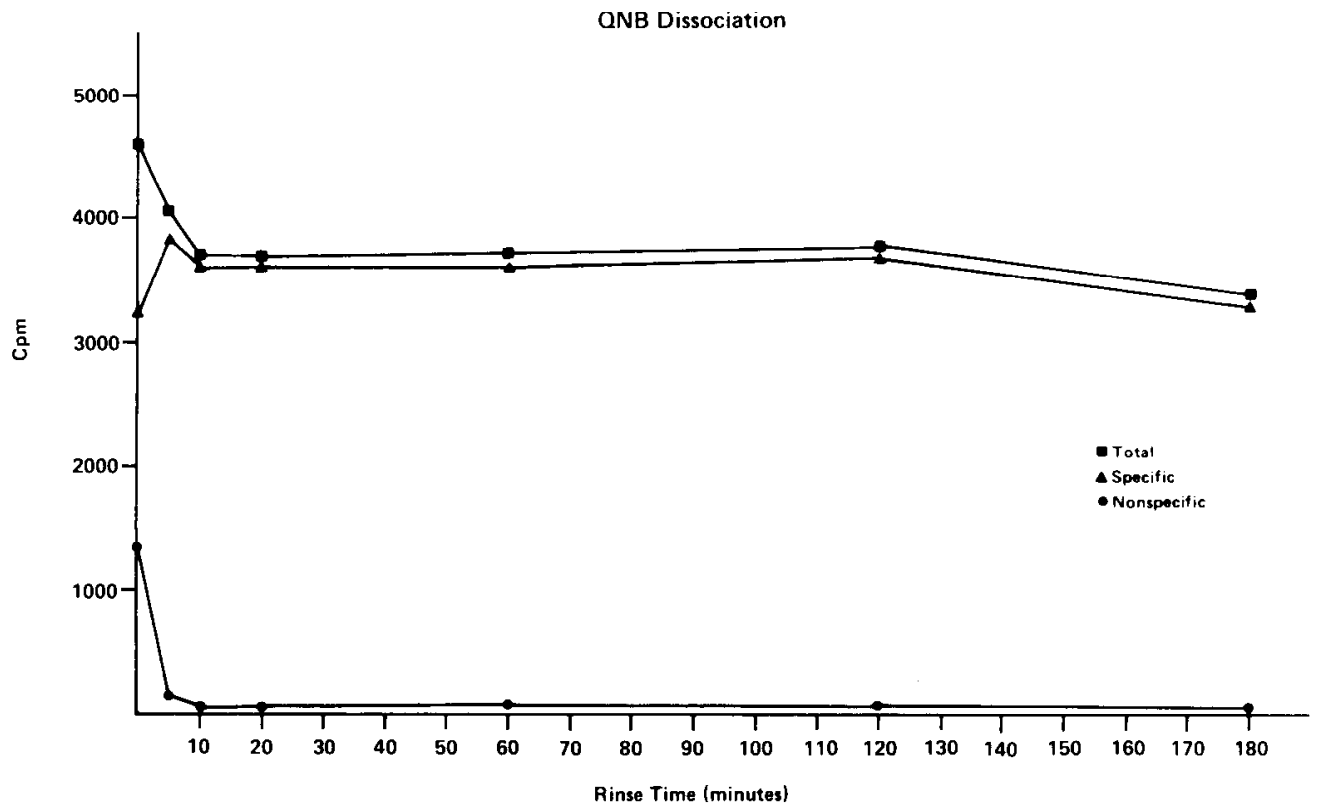

Figure 1. Dissociation analysis of $\left[{ }^{3} \mathrm{H}\right] \mathrm{QNB}$ to tissue sections. Ten-micrometer tissue sections were incubated for $1 \mathrm{hr}$ in $1 \mathrm{nM}\left[{ }^{3} \mathrm{H}\right] \mathrm{QNB}$ followed by various rinsing times. Virtually all nonspecific binding was rinsed away after $10 \mathrm{~min}$ in buffer without severely impairing the amount of specific binding. Each point represents the average of results from at least three different experiments whose data varied less than $10 \%$.



Figure 2. Association analysis of $\left[{ }^{3} \mathrm{H}\right] \mathrm{QNB}$ to tissue sections. Tissue sections were incubated for various amounts of time in $1 \mathrm{nM}\left[{ }^{3} \mathrm{H}\right] \mathrm{QNB}$ followed by two 5 -min rinses. Each point represents the average of results from at least three different experiments whose data varied less than $10 \%$.

muscarinic cholinergic receptors with $\left[{ }^{3} \mathrm{H}\right] \mathrm{QNB}$ using a 2-hr, room temperature incubation followed by two 5min rinses in PBS. This experiment shows a half-maximal saturation concentration of about $0.2 \times 10^{-9} \mathrm{M}$ and most receptors are occupied at $1.0 \mathrm{nM}$ concentrations of $\left[{ }^{3} \mathrm{H}\right]$ QNB. Scatchard analysis gave a $K_{d}$ value of $0.27 \times 10^{-9}$ $M$ and a $B_{\max }$ of $48.0 \mathrm{fmol} / \mathrm{mg}$ of tissue in tissue sections consisting of predominantly striatum and frontal cortex. A Hill plot of the data obtained gave a slope of 1.0, indicating there is no cooperativity.
Figure 4 shows the pharmacological specificity of QNB for the muscarinic cholinergic receptor by demonstrating the displacement of $\left[{ }^{3} \mathrm{H}\right] \mathrm{QNB}$ binding to the tissue sections incubated in the presence of atropine, scopolamine, or pilocarpine. These compounds show $\mathrm{IC}_{50}$ values of 1.0 $\times 10^{-8} \mathrm{M}, 4.0 \times 10^{-9} \mathrm{M}$, and $8.0 \times 10^{-5} \mathrm{M}$, respectively. The nicotinic antagonists, tubocurare and hexamethonium, had no effect on $\left[{ }^{3} \mathrm{H}\right] \mathrm{QNB}$ binding until a concentration of $10^{-3} \mathrm{M}$ was obtained. Even at this high concentration, only a $15 \%$ displacement was noted. 
Autoradiographic studies. Tissues were prepared for autoradiography as described under "Materials and Methods." Autoradiograms of most of the areas of brainstem (other than those specifically mentioned in this communication) contained a uniformly distributed low concentration of autoradiographic grains. There were a few exceptions, however, most notably the superior olive (Fig. 6) which had few, if any, binding sites for $\left[{ }^{3} \mathrm{H}\right] \mathrm{QNB}$.

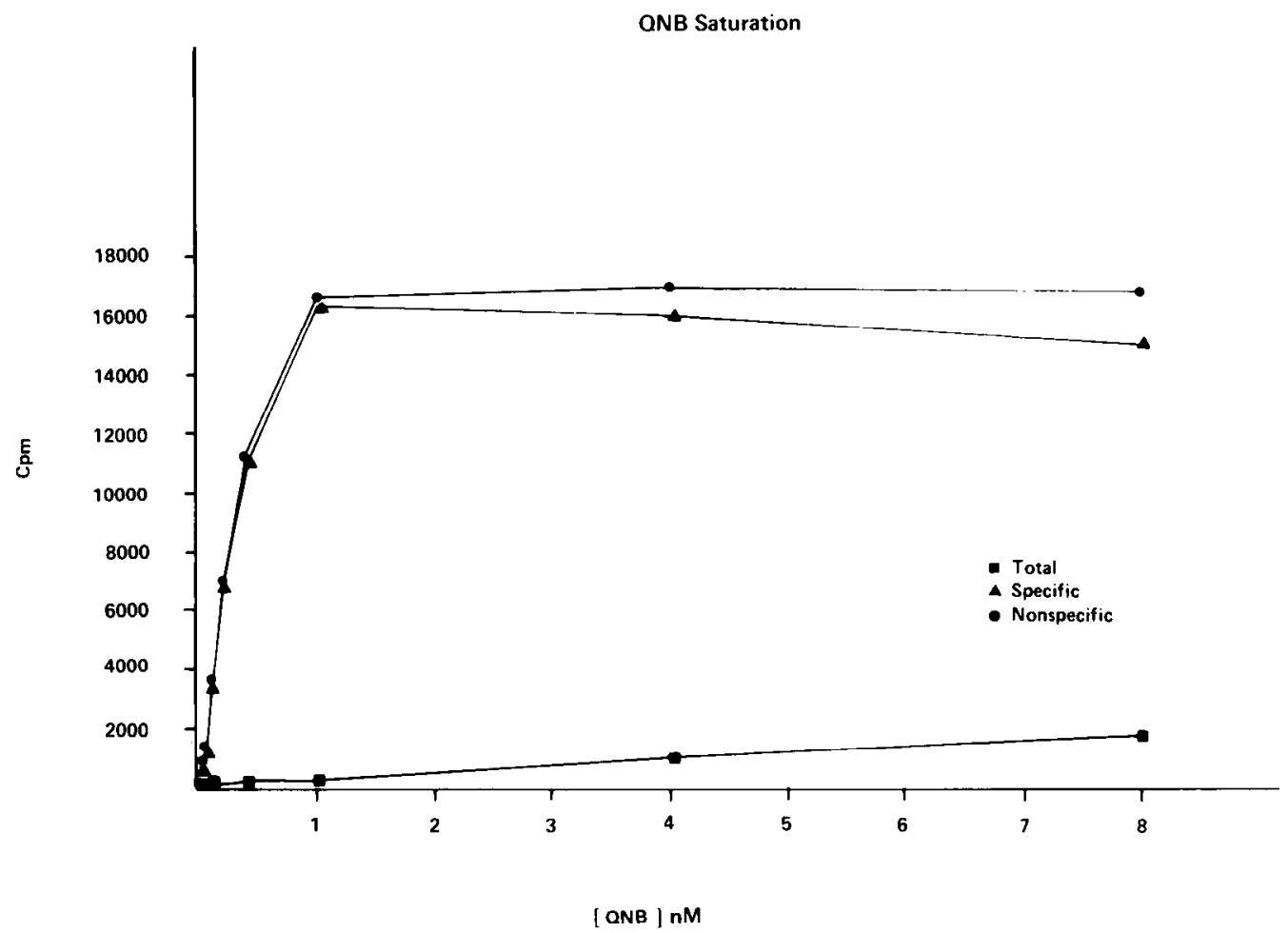

Figure 3. Saturation analysis of $\left[{ }^{3} \mathrm{H}\right] \mathrm{QNB}$ to tissue sections. Slide-mounted tissue sections were incubated for $2 \mathrm{hr}$ (room temperature) in varying concentrations of [ $\left.{ }^{3} \mathrm{H}\right] \mathrm{QNB}$ followed by two 5-min rinses. Each point represents the average of results from at least three different experiments whose data varied less than $10 \%$.

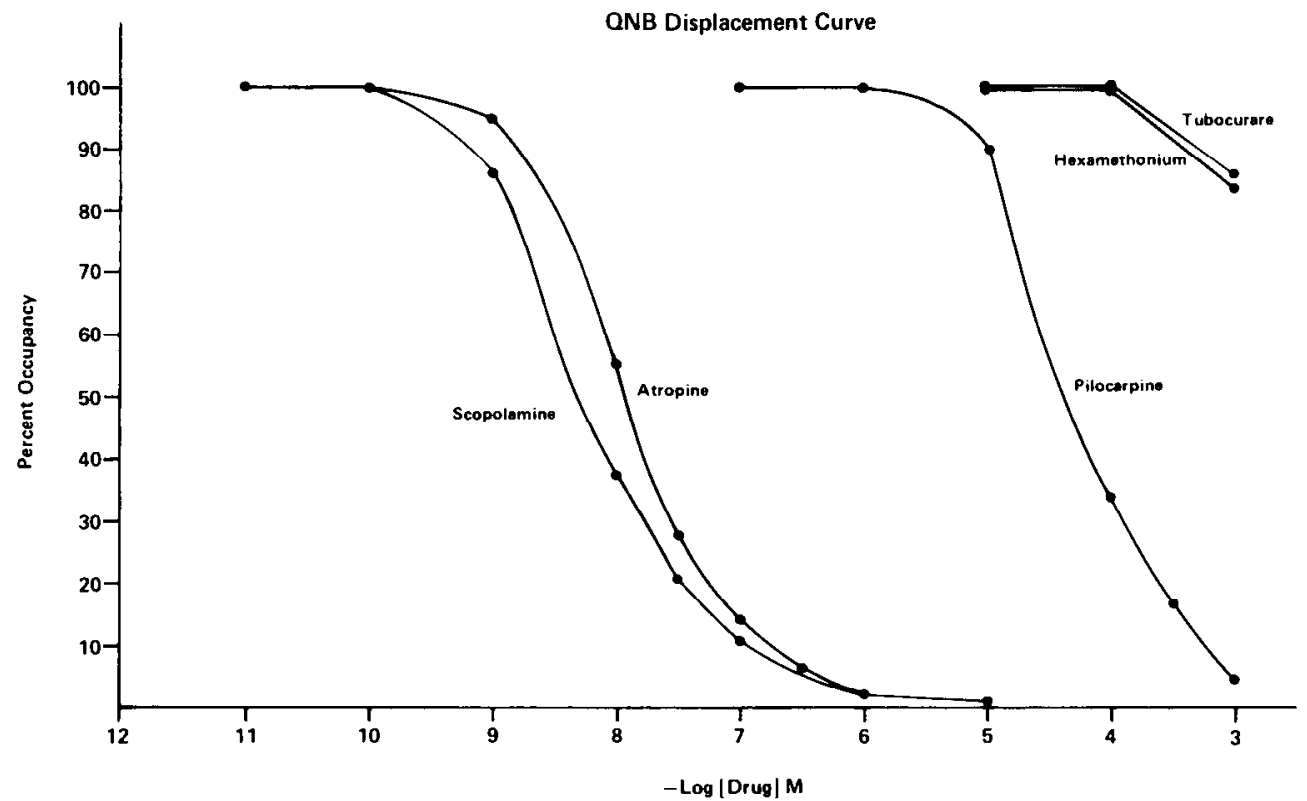

Figure 4. Displacement analysis of $\left[{ }^{3} \mathrm{H}\right] \mathrm{QNB}$ to tissue sections. $\left[{ }^{3} \mathrm{H}\right] \mathrm{QNB}$ was displaced from the muscarinic binding sites in the slide-mounted tissue sections with varying concentrations of scopolamine, atropine, and pilocarpine. The nicotinic antagonists, hexamethonium and tubocurare, had very little effect on $\left[{ }^{3} \mathrm{H}\right] \mathrm{QNB}$ binding, indicating the specificity of the ligand for the muscarinic cholinergic receptor. Each point represents the average of results from at least three different experiments whose data varied less than $10 \%$. 


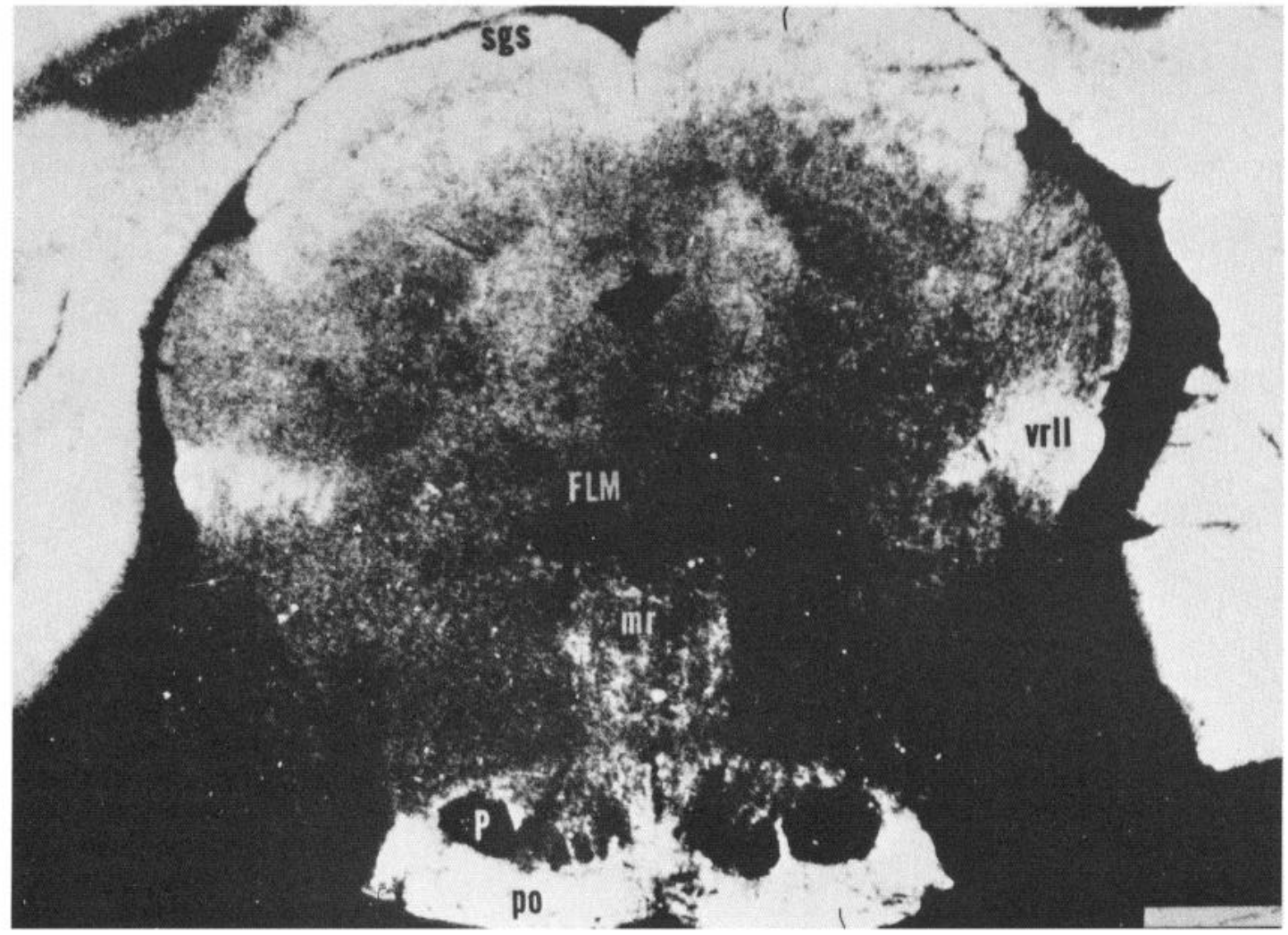

Figure $5 .^{2}$ Autoradiographic grain densities in the caudal midbrain. This photomicrograph was taken under dark-field illumination and shows the autoradiographic grain distribution on the coverslip over tissue incubated with [ $\left.{ }^{3} \mathrm{H}\right] \mathrm{QNB}$. The tissue section itself is slightly below this plane of focus and cannot be seen. Note the dense labeling of the superior colliculus (sgs), the ventral rostral nucleus of the lateral lemniscus $(v r l l)$, and the pontine nuclei $(p o)$. Note also the low amount of labeling in the white matter areas medial longitudinal fasciculis $(F L M)$ and corticospinal tract $(P)$. Many areas of low to intermediate grain density are not discernible on these low magnification, high contrast photographic reproductions, although they are referred to in the text. Bar $=1 \mathrm{~mm}$.

High contrast paper was used to print Figures 5 to 11 . As a result, some areas of low to intermediate grain densities were lost in the photographic reproduction process. These regions are described in the text and the reader is

\footnotetext{
${ }^{2}$ The abbreviations used on the figures are: amb, nucleus ambiguus; BCI, brachium colliculi inferioris; CI, colliculus inferior; cod, nucleus cochlearis dorsalis; cov, nucleus cochlearis ventralis; $\mathrm{ct}$, nucleus corporis trapezoidei; CT, corpus trapezoideum; cu, nucleus cuneatus; cul, nucleus cuneatus lateralis; DP, decussatio pyramidis; $d r$, nucleus dorsalis raphes; FC, fasciculus cuneatus; FG, fasciculus gracilis; FL, fasciculus longitudinalis; FLM, fasciculus longitudinalis medialis; FOR, formatio reticularis; gr, nucleus gracilis; io, nucleus olivaris inferior; lc, locus coeruleus; LM, lemniscus medialis; mr, nucleus medianus raphes; nco, nucleus commissuralis; nic, nucleus intercalatus; npd, nucleus parabrachialis dorsalis; npv, nucleus parabrachialis ventralis; $n p V$, nucleus principalis nervi trigemini; nrd, nucleus reticularis medullae oblongatae pars dorsalis; nrv, nucleus reticularis medullae oblongatae pars ventralis; ntd, nucleus tegmenti dorsalis Gudden; ntdl, nucleus tegmenti dorsalis lateralis; ntm, nucleus tractus mesencephali; nts, nucleus tractus solitarius; ntv, nucleus tegmenti ventralis Gudden; ntV, nucleus tractus spinalis nervi trigemini; ntVd, nucleus tractus spinalis nervi trigemini pars dorsomedialis; $\mathrm{nV}$, nucleus originis nervi trigemini; $\mathrm{nVII}$, nucleus originis nervi facialis; $\mathrm{nXII}$, nucleus originis nervi hypoglossi; $\mathrm{OC}$, tractus olivocerebellaris; ope, nucleus preolivaris externus; os, nucleus olivaris superior; osa, nucleus accessorius olivaris superioris; osp, nucleus parvolivaris superioris; P, tractus corticospinalis; PCI, pedunculus cerebellaris inferior; PCM, pedunculus cerebellaris medius;
}

referred to representations of these areas in the schematics (Figs. 12 and 13).

Mesencephalon. Very high concentrations of autoradiographic grains were localized over the superficial layers of the superior colliculus (stratum griseum superficiale and stratum opticum colliculi superioris; Figs. 5 and 12). Slightly lower numbers of grains (but still a very

PCS, pedunculus cerebellaris superior; ph, nucleus prepositus hypoglossi; pl, nuclei pontis, pars lateralis; pm, nuclei pontis, pars medialis; po, nuclei pontis; ps, nucleus parasolitarius; rgi, nucleus reticularis gigantocellularis; $\mathrm{rl}$, nucleus reticularis lateralis; $r \mathrm{rm}$, nucleus raphe magnus; rpc, nucleus reticularis parvocellularis; rpo, nucleus raphe pontis; rpoc, nucleus reticularis pontis caudalis; rpoo, nucleus reticularis pontis oralis; rrp, nucleus reticularis tegmenti pontis; SAM, stratum album mediale colliculi superioris; SGCD, substantia grisea centralis, pars dorsalis; SGCL, substantia grisea centralis, pars lateralis; SGCV, substantia grisea centralis, pars ventralis; SGM, stratum griseum mediale colliculi superioris; sgs, stratum griseum superficiale colliculi superioris; $\mathrm{sgV}$, substantia gelatinosa trigemini; SO, stratum opticum colliculi superioris; $\mathrm{tmV}$, nucleus tractus mesencephali nerve trigemini; tp, nucleus tegmenti pontis; TRS, tractus rubrospinalis; TS, tractus solitarius; TSV, tractus spinalis nervi trigemini; V, nervus trigeminalis; vcll, nucleus ventralis caudalis lemnisci lateralis; VII, nervus facialis; vl, nucleus vestibularis lateralis; vm, nucleus vestibularis medialis; VM, nervus trigeminus, radix motoria; vrll, nucleus ventralis rostralis lemnisci lateralis; VS, nervus trigeminus, radix sensoria; vsp, nucleus vestibularis spinalis. 


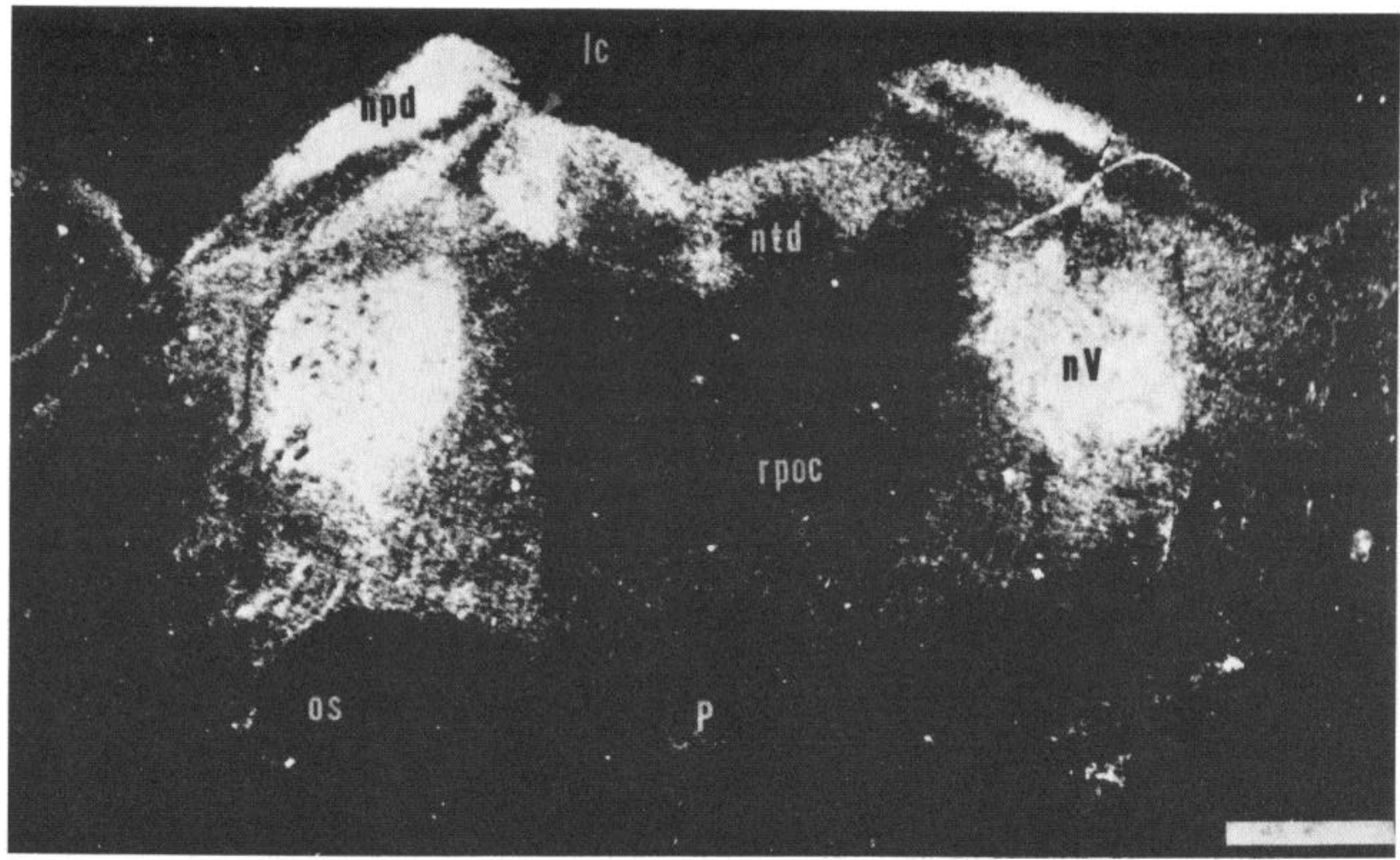

Figure 6. Low magnification dark-field photomicrograph through caudal pons. In this autoradiogram, notice the heavy labeling of the nucleus of the trigeminal nerve $(n V)$ and the dorsal parabrachial nucleus $(n p d)$. In this photomicrograph, it can be appreciated that there is very little labeling of the superior olive (os). Bar $=1 \mathrm{~mm}$.

dense concentration) were observed over the stratum griseum mediale colliculi superioris and the stratum album mediale colliculi superioris.

Very high concentrations of $\left[{ }^{3} \mathrm{H}\right] \mathrm{QNB}$ binding sites could also be demonstrated in the midbrain in the ventral rostral nucleus of the lateral lemniscus (parabigeminal nucleus). This nucleus contained the highest concentration of grains when compared to all other brainstem areas examined (Table I). Very high grain concentrations were also identified in the ventral caudal nucleus of the lateral lemniscus (Figs. 5 and 12) and in the gray matter surrounding the dorsal tegmental nucleus of Gudden (Figs. 6 and 12). Somewhat lower levels of autoradiographic grains could be found over the trochlear nucleus (IV) and along the dorsal and lateral aspects of the inferior colliculus (not shown).

Intermediate concentrations of $\left[{ }^{3} \mathrm{H}\right] \mathrm{QNB}$ binding sites were seen throughout the periaqueductal gray matter (Figs. 5 and 12) with slightly higher concentrations in the dorsal (substantia grisea centralis, pars dorsalis) and lateral (pars lateralis) portions. Intermediate grain densities were also seen in the medial raphe nucleus (Figs. 5 and 12), in caudal parts of the dorsal raphe nucleus (not shown), and over the dorsal and ventral tegmental nuclei of Gudden (Fig. 12).

Metencephalon. The cranial nerve nuclei, trigeminal (V) and facial (VII), demonstrated very high concentrations of autoradiographic grains in sections taken through pontine levels of the brainstem (Figs. 6, 8, 12, and 13). Ventral divisions of the pontine nuclei themselves (nu- cleus pontis pars lateralis and medialis) also contain very high numbers of grains (Figs. 5 and 12). The dorsal parabrachial nucleus was seen to have a very high number of $\left[{ }^{3} \mathrm{H}\right] \mathrm{QNB}$ binding sites, while the ventral parabrachial nucleus demonstrated a very high concentration of autoradiographic grains in pontine levels which diminished somewhat in more rostral regions of its extent (Figs. 6, 7, and 12). The locus coeruleus, on the other hand, had more autoradiographic grains in its rostral divisions than it did in more caudal areas (Figs. 6 and 12).

High levels of grains were found over the nucleus tegmenti pontis (Figs. 5 and 12), the nucleus tractus spinalis nervi trigemini, pars dorsomedialis (Figs. 8, 12, and 13), the substantia gelatinosa trigemini (Figs. 10 and 13), and the medial vestibular nucleus (Figs. 8 and 13). High levels of autoradiographic grains could also be seen lining the dorsolateral borders of the dorsal and ventral cochlear nuclei (Figs. 12 and 13).

Intermediate numbers of $\left[{ }^{3} \mathrm{H}\right] \mathrm{QNB}$ binding sites could be demonstrated over the parvocellular reticular nucleus (Figs. 9 and 13), over the mesencephalic (Figs. 6, 7, and 12) and spinal nuclei (Figs. 9, 10, and 13) of the trigeminal nerve, and over the superior and lateral vestibular nuclei (Fig. 13). A fairly uniform concentration of autoradiographic grains was also seen situated around the deep cerebellar nuclei associated with portions of the middle and superior cerebellar peduncles (Figs. 12 and 13). Only low numbers of grains were seen associated with pontine reticular nuclei (nucleus reticularis pontis oralis, Fig. 12; 

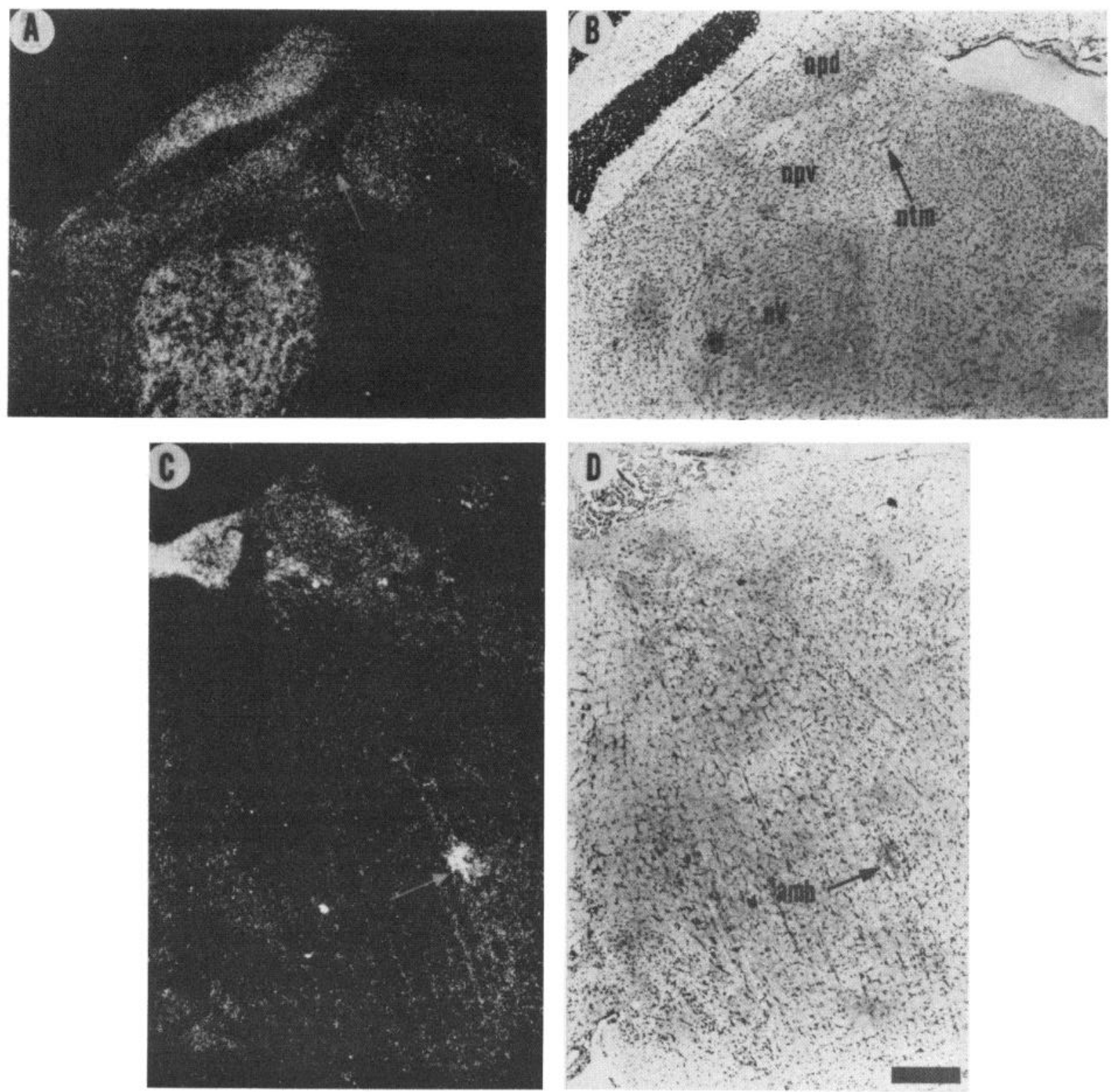

Figure 7. Bright-field and dark-field photomicrographs of areas in the pons and medulla. A, Higher magnification of a dorsolateral area shown in Figure 6. B. Bright-field photomicrograph of the stained tissue section immediately underneath the coverslip shown in $A$. These photomicrographs were generated by taking $A$ under dark-field illumination and then switching to bright-field without moving the microscope stage and photographing the tissue underneath. $C$, Dark-field photomicrograph showing the grain density over this level containing the nucleus ambiguus (arrow). $D$, Bright-field photomicrograph of the tissue immediately under the coverslip shown in $C . B a r=100 \mu \mathrm{m}$.

nucleus reticularis tegmenti pontis, Fig. 12; nucleus reticularis pontis caudalis, Figs. 6 and 12; and nucleus reticularis gigantocellularis, Figs. 8, 9, and 13). The nucleus raphe pontis, nucleus parvolivaris superioris, nucleus principalis nervi trigemini (Fig. 12), and the nucleus of the abducens (VI) nerve (not shown) were also found to demonstrate a low concentration of autoradiographic grains.

Myelencephalon. The hypoglossal (XII) nucleus (Figs. 9,10 , and 13) and the nucleus ambiguus (Fig. 7) contained the highest concentrations of autoradiographic grains in the medulla. The nucleus tractus solitarius (Figs. 9 and 13), nucleus parasolitarius, nucleus cuneatus lateralis, nucleus prepositus hypoglossi, and the nucleus reticularis lateralis (Fig. 13) contained high densities of $\left[{ }^{3} \mathrm{H}\right] \mathrm{QNB}$ binding sites.

Intermediate levels of grains could be localized over the gracile and cuneate nuclei (Figs. 10 and 13), over the inferior olive (Figs. 9 and 13) and accessory olivary nuclei (pars dorsalis and medialis), and over the medullary reticular nuclei (pars dorsalis and ventralis, Figs. 10 and 13). 
Low levels of grains could be seen associated with the dorsal motor nucleus of the vagus, nucleus intercalatus, nucleus commissuralis, and the nucleus basilaris internus of Cajal (Fig. 13).

Spinal cord. We examined the upper levels of the cervical spinal cord and found a dense concentration of autoradiographic grains in the substantia gelatinosa (Fig. 11). High levels of grains were seen over lamina IX and $\mathrm{X}$ and over the medial portions of lamina VII and VIII. Intermediate levels of grains existed in other portions of
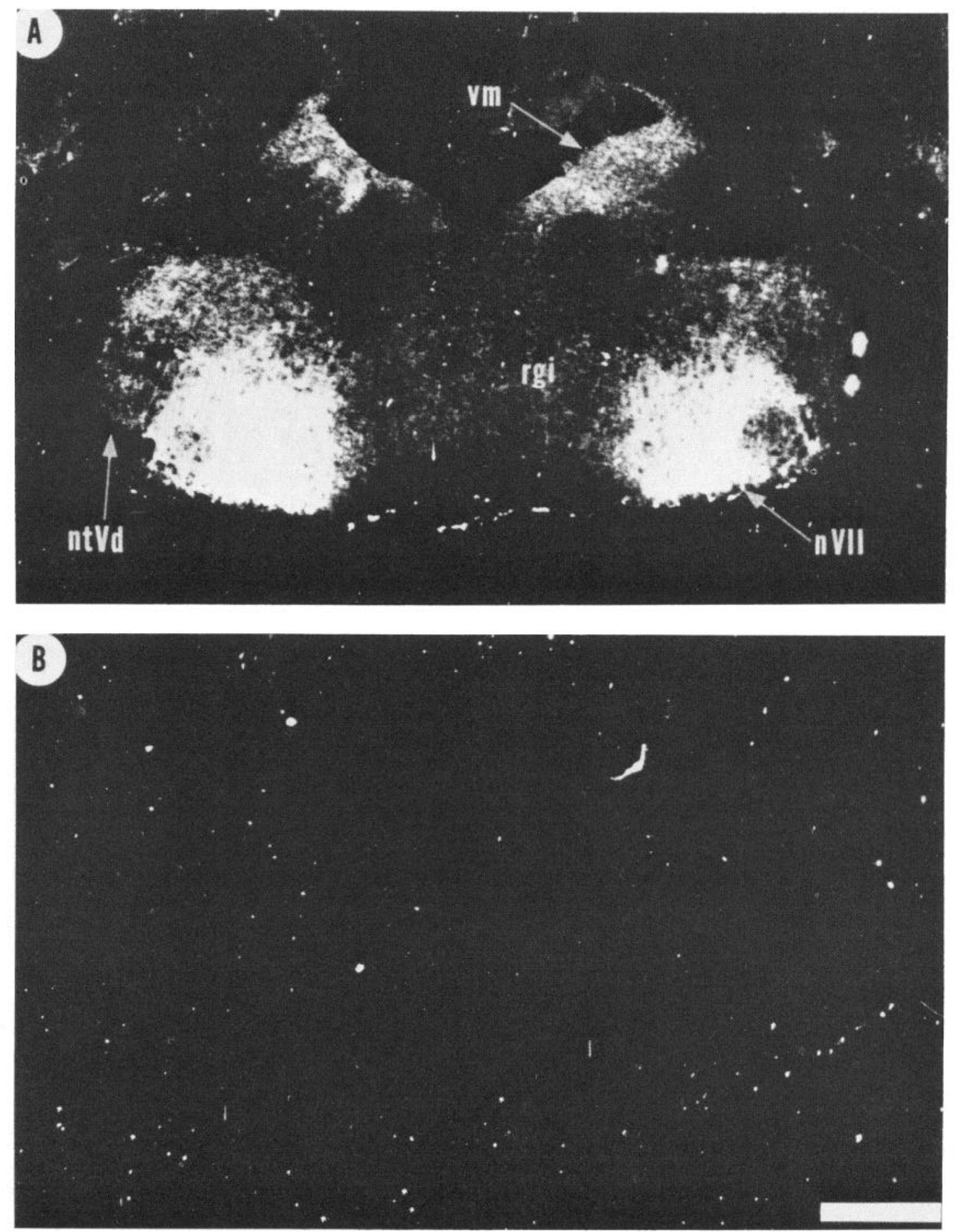

Figure 8. Autoradiographic demonstration of $\left[{ }^{3} \mathrm{H}\right] \mathrm{QNB}$ binding in the vestibular area. $A$, Dark-field photomicrograph demonstrating the concentration of autoradiographic grains seen over the medial vestibular nucleus $(\mathrm{vm})$ and over the nucleus of the facial nerve $(n V I I)$. B, This dark-field photomicrograph depicts an adjacent section which was incubated under the same conditions as the tissue in $A$, but the incubation media contained $1 \mu \mathrm{M}$ unlabeled atropine. The grains in this photograph indicate areas of nonspecific binding. $B a r=1 \mathrm{~mm}$. 

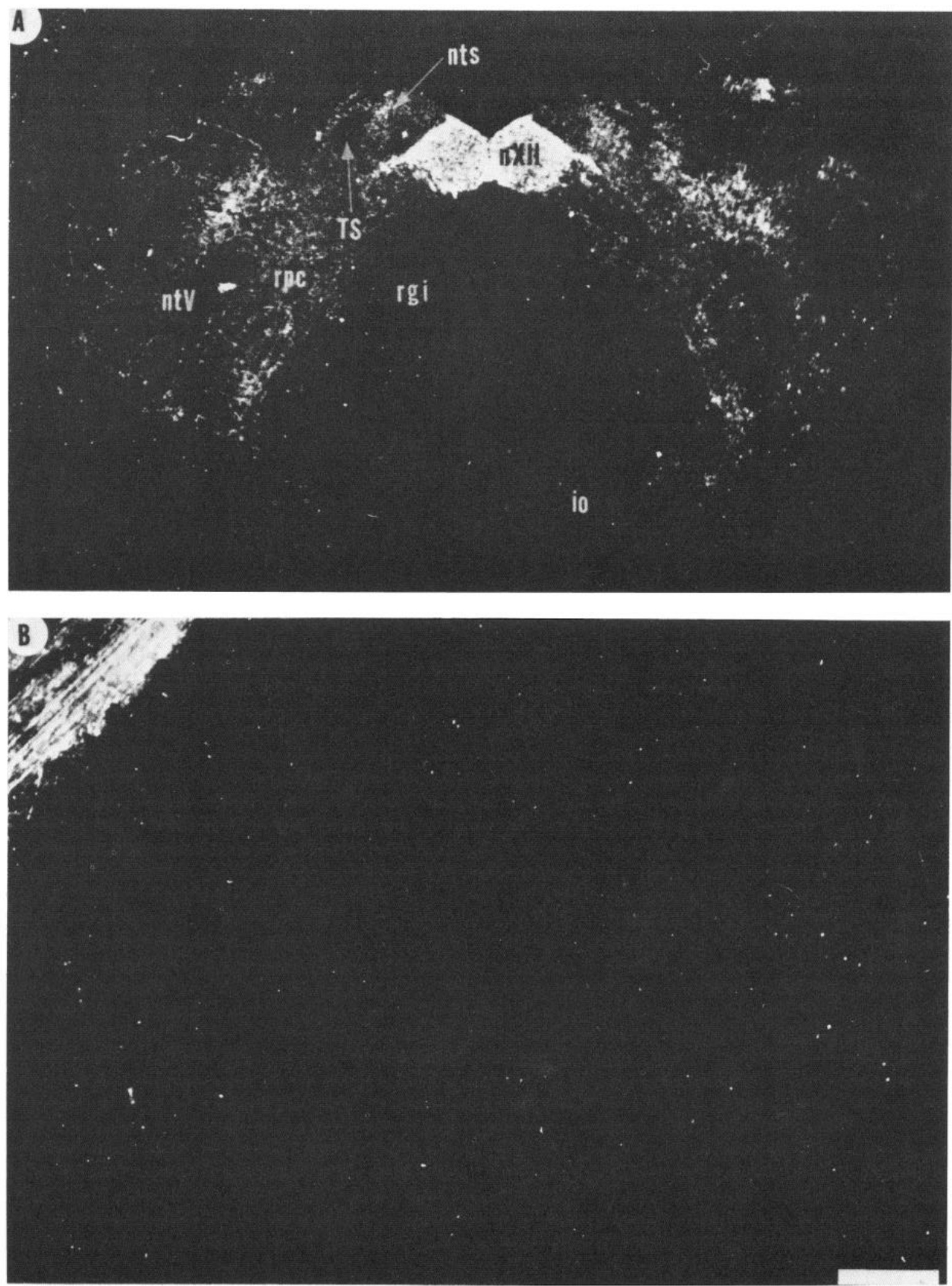

Figure 9. Photomicrograph of grain densities in the rostral medulla. A, Most of the autoradiographic grains demonstrated in this photomicrograph appear concentrated in the nuclei of the hypoglossal nerves ( $n X I I)$. Note also the labeling of the nucleus tractus solitarius (nts), while the tract itself $(T S)$ is not labeled. B, Control dark-field photomicrograph of a tissue section incubated in the presence of $1 \mu \mathrm{M}$ atropine to effectively compete off the specific $\left[{ }^{3} \mathrm{H}\right] \mathrm{QNB}$ binding. Bar $=1 \mathrm{~mm}$. 


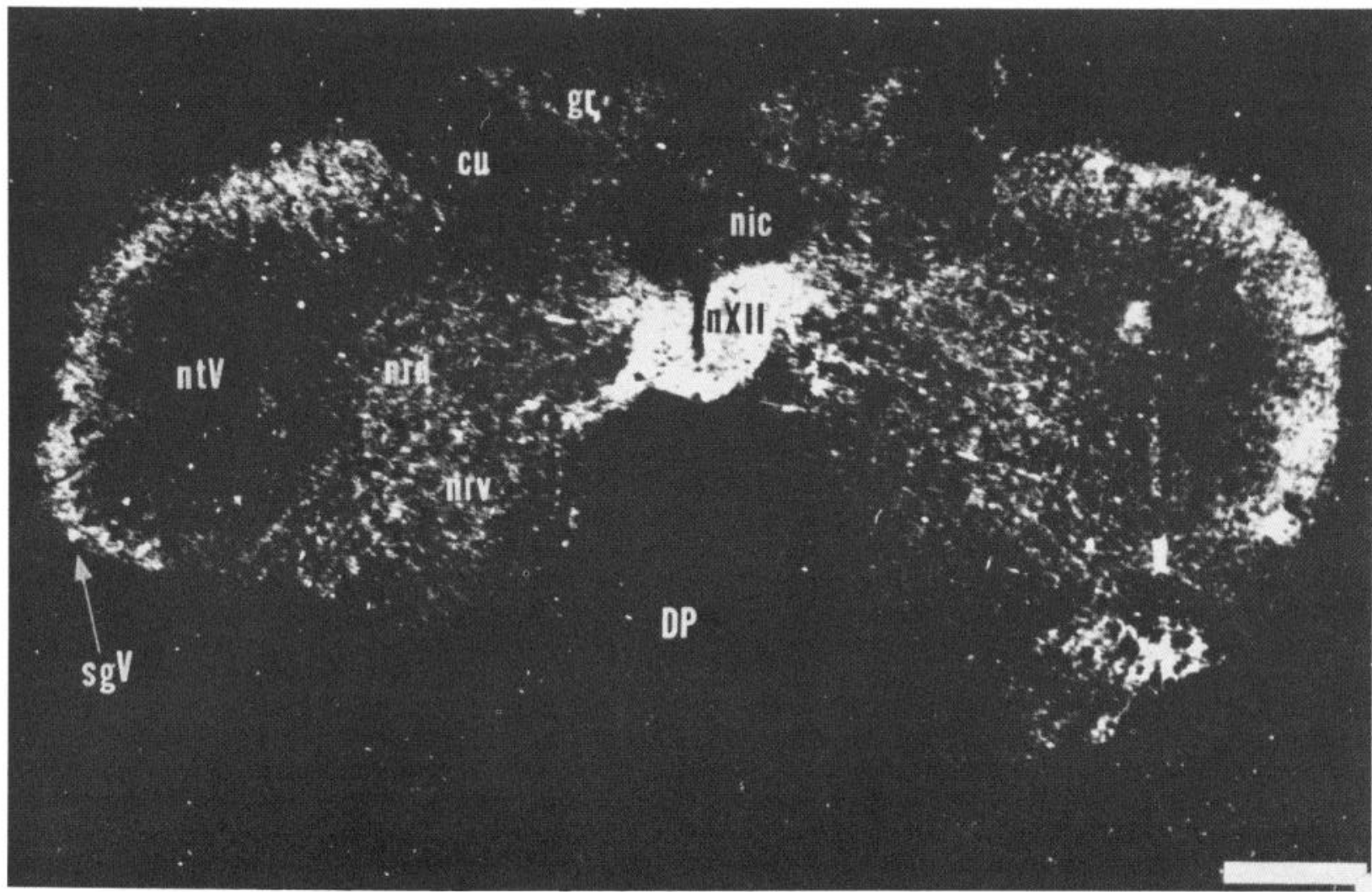

Figure 10. Photomicrograph demonstrating muscarinic receptors in the caudal medulla. Again, in this dark-field photomicrograph, the dense labeling of the nucleus of the hypoglossal nerve can be appreciated $(n X I I)$. Note also the slight labeling of the sensory nuclei-nucleus gracilis $(\mathrm{gr})$, cuneatus $(\mathrm{cu})$, and spinal trigeminal nucleus $(\mathrm{sg} V$ ). $\mathrm{Bar}=1 \mathrm{~mm}$.

lamina VII and VIII and in lamina III and V. Lamina IV contained the least amount of grains at this spinal cord level.

\section{Discussion}

The autoradiographic technique (Young and Kuhar, 1979) employed in this communication seems well suited for the autoradiographic localization of muscarinic cholinergic receptors using $\left[{ }^{3} \mathrm{H}\right] \mathrm{QNB}$. Specific to nonspecific ratios 6 -fold higher than any previously reported were found routinely here. This means very precise identifications of nuclei containing muscarinic cholinergic receptors could be accomplished with relatively little concern for background levels of nonspecific binding.

The ability to parallel closely the detailed biochemical results found in brain homogenate studies using QNB indicates that we are labeling muscarinic cholinergic binding sites in our tissue sections. Scatchard analysis of the binding characteristics shows an affinity and density of receptors similar to that reported in the literature for homogenates and slices (Yamamura and Snyder, 1974; Snyder et al., 1975; Yamamura et al., 1976; Hanley and Iversen, 1978). Hill plots of the data show that the ligand is obeying classic mass action laws in tissue sections as one would expect for QNB. The displacement curves for the antagonists, atropine and scopolamine, and the partial agonist-antagonist, pilocarpine, are similar to those previously reported for QNB, especially those by Hanley and Iversen (1978) who studied binding in slices at $20^{\circ} \mathrm{C}$ as we have.

Our receptor localizations agree well with those of Rotter et al. (1979a, b) who employed $\left[{ }^{3} \mathrm{H}\right]$ propylbenzilylcholine $\left(\left[{ }^{3} \mathrm{H}\right] \operatorname{PrBCM}\right)$ mustard. However, some of our findings were not reported by Rotter et al. (1979b). For example, we found very high concentrations of muscarinic cholinergic binding sites in the dorsal parabrachial nucleus; high concentrations of grains in the ventral parabrachial nucleus, nucleus parasolitarius, and nucleus prepositus hypoglossi; and low concentrations of muscarinic cholinergic binding sites in the nucleus parvolivaris superioris, nucleus basilaris internus (Cajal), nucleus commissuralis, nucleus intercalatus, and the nucleus of the abducens nerve (VI). We noted relatively higher concentrations of muscarinic cholinergic binding sites in certain brain regions, such as the locus coeruleus and the nucleus tractus solitarius, and we noted the restriction of grains to subdivisions of some specific nuclei, such as the dorsal and ventral cochlear nuclei and the inferior colliculus. The present study also included an examination of the muscarinic cholinergic binding sites in the spinal cord which has not been reported previously.

The technique presented here allows the localization of muscarinic cholinergic receptors with relative ease and precision because of the low background. The advantage of the $\left[{ }^{3} \mathrm{H}\right] \operatorname{PrBCM}$ compound is that, since it binds irreversibly by forming a covalent bond, it can be used 

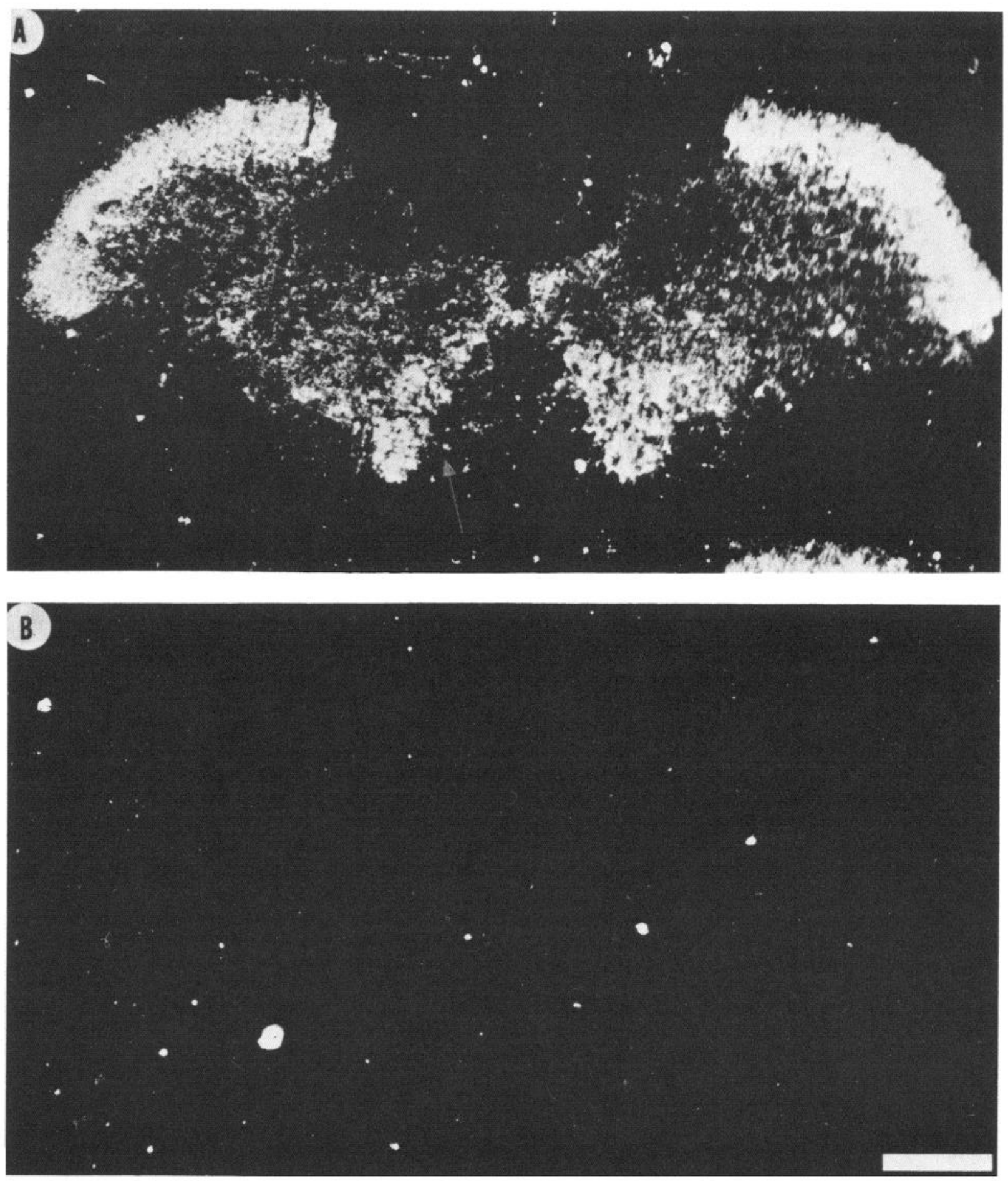

Figure 11. [ $\left.{ }^{3} \mathrm{H}\right] \mathrm{QNB}$ binding sites in the spinal cord. A, Dark-field photomicrograph showing the autoradiographic grain distribution on the coverslip over a tissue section taken through the upper level of the cervical spinal cord. Note the heavy labeling in the substantia gelatinosa of the dorsal horn and the concentration of grains in parts of the ventral horn. Note also how some of the grains in the ventral horn radiate out into the surrounding white matter (arrow). $B$, Adjacent section incubated in the presence of atropine. $B a r=1 \mathrm{~mm}$.

for electron microscopic autoradiographic localization of the muscarinic cholinergic binding site (Kuhar et al., 1979).

Reports in the literature have indicated the existence of multiple agonist binding sites for muscarinic cholinergic agents (Birdsall et al., 1978). Since QNB is a very potent antagonist and its displacement with other antag- onists follows the laws of mass action, we can assume that the $\left[{ }^{3} \mathrm{H}\right] \mathrm{QNB}$ is labeling all sites with a uniform high affinity (Hulme et al., 1978). It is possible, however, to distinguish multiple agonist binding sites for muscarinic cholinergic drugs, employing autoradiographic techniques as outlined elsewhere (Wamsley et al., 1980).

In several instances, we found nuclei which did not 
have a uniform distribution of autoradiographic grains. Some of these non-uniformities could be explained by examining the layering of the internal cellular structure of these nuclei. For example, the inferior colliculus demonstrated high levels of grains "capping" a central area of the colliculus which contained only low levels of grains. The inferior colliculus is known to consist of a central nucleus which is covered by a narrow band of cortex, indicating that the muscarinic cholinergic binding sites are located predominantly in the cortex. Also, the cochlear nuclei in the brainstem were observed to have discontinuous bands of autoradiographic grains as mentioned above. These bands, however, correspond to the layer of granule cells of the cochlear nuclei. The function of these cells is unknown, but they are thought to receive cholinergic collaterals from the superior olive (Rasmus-
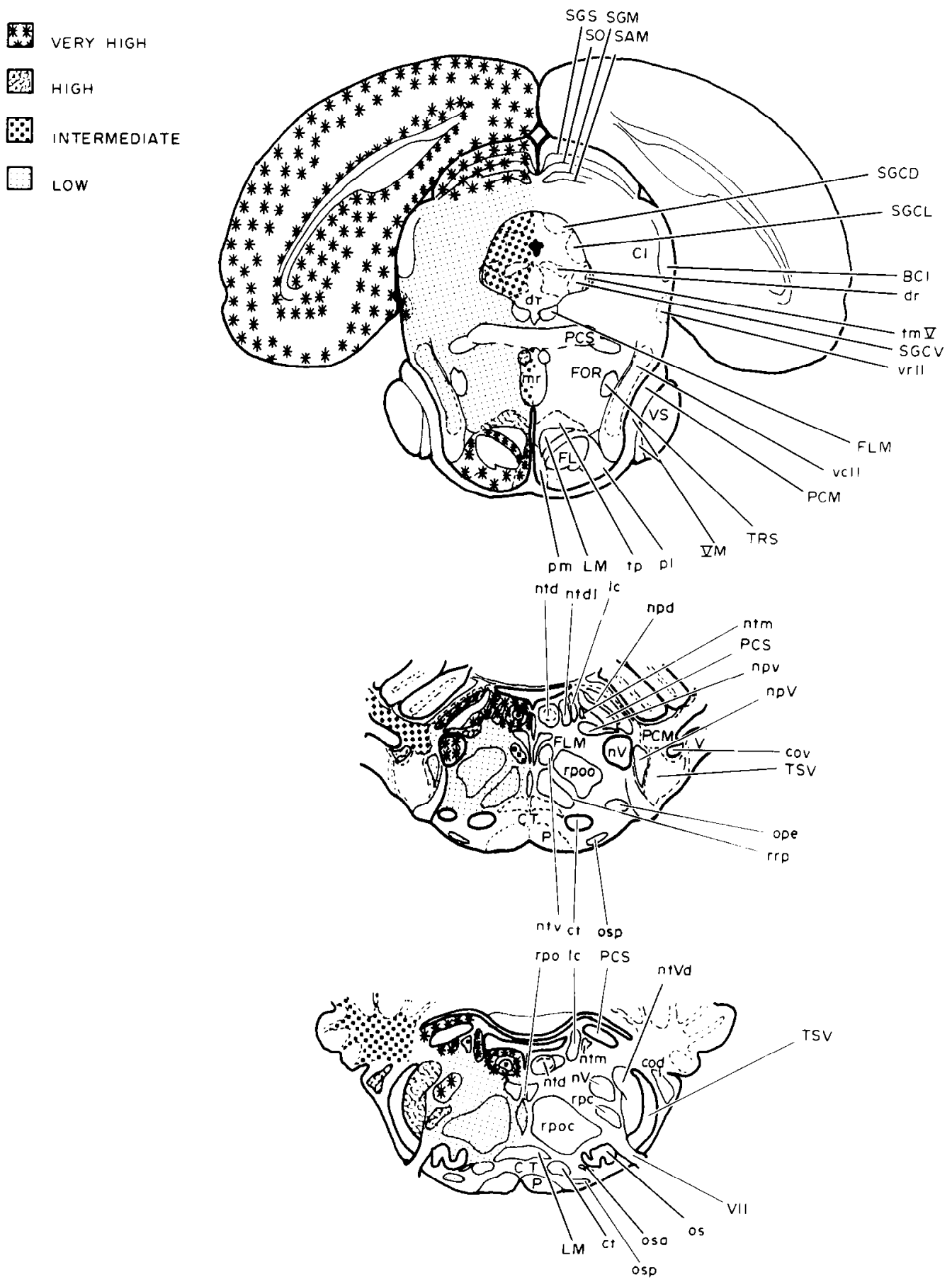

Figure 12. Schematics of the autoradiographic grain distributions through several layers of the brainstem. The highest grain densities at these levels occurred in the superior colliculus, ventral rostral nucleus of the lateral lemniscus, pontine nuclei, dorsal parabrachial nucleus, locus coeruleus, dorsal tegmental nucleus, and the nucleus of the trigeminal nerve. Anatomically defined areas are designated according to Konig and Klippel (1963) and Palkovits and Jacobowitz (1974). 

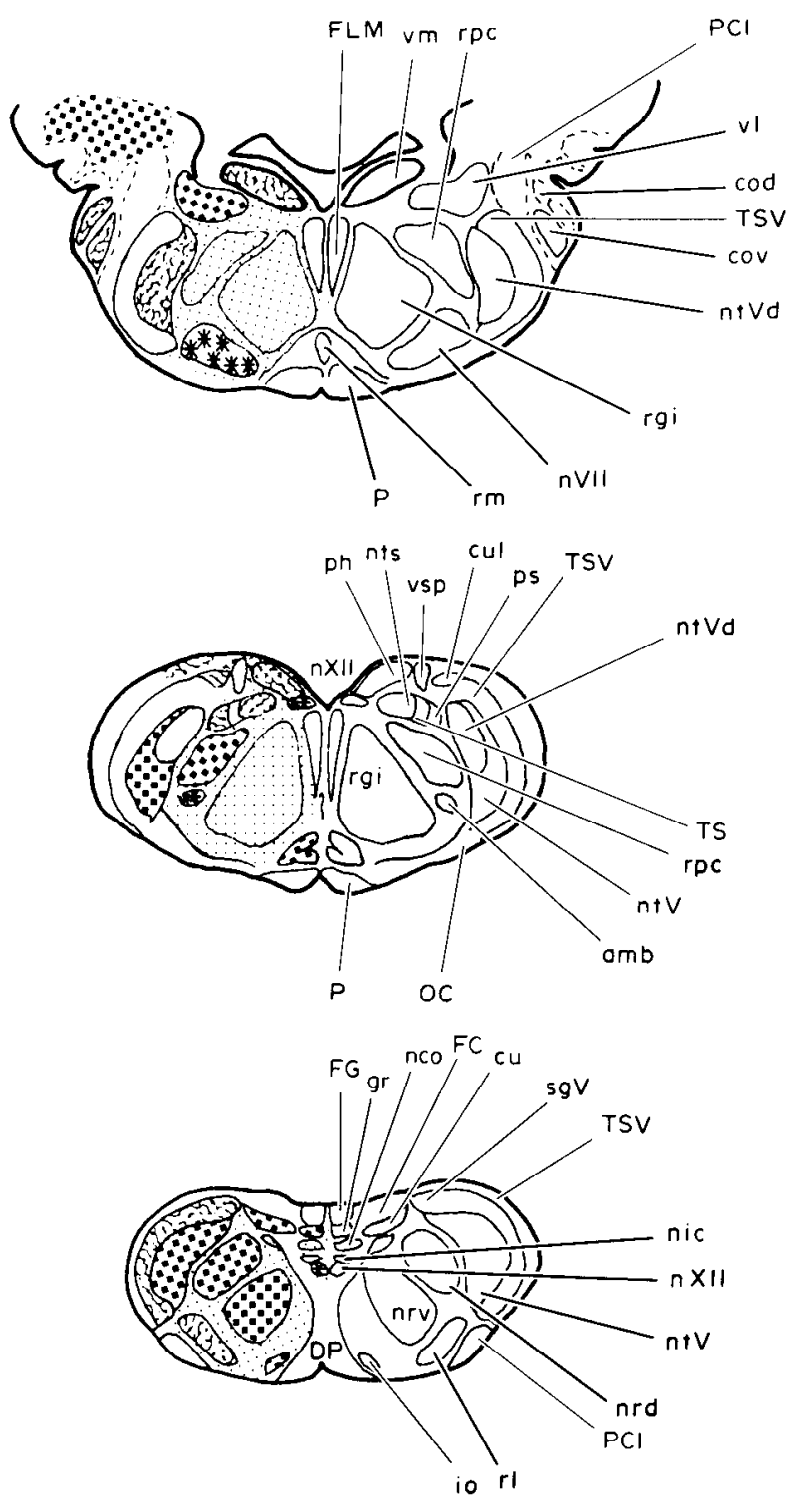

Figure 13. Schematics of autoradiographic grain densities indicating the position of muscarinic cholinergic binding sites in caudal areas of the brainstem. Very high concentrations of grains from these sections were found over the nucleus of the facial nerve, nucleus of the hypoglossal nerve, and the nucleus ambiguus. Anatomically defined areas are designated according to Palkovits and Jacobowitz (1974).

sen, 1967) via the olivo-cochlear bundle and may be involved in regulating the firing of pyramidal cells in the cochlear nuclei (Osen, 1969).

We localized high concentrations of muscarinic binding sites associated with the motor cranial nerve nuclei VII and XII. These nerves innervate skeletal musculature of the face and tongue and thus control voluntary movement of these structures. Our localization of muscarinic cholinergic receptor sites in the ventral horn of the spinal cord may also demonstrate a potential site for acetylcholine to centrally affect voluntary movement. The $\alpha$ motor neurons which innervate skeletal musculature via the spinal nerves are known to have their cell somata in the ventral horn of the gray matter. Some of the large motor neuron cell bodies have dendritic arborizations which extend out into the surrounding anterolateral funiculus. We have identified "spicules" of autoradiographic grains extending out into these white matter areas and speculate that these receptors are located on the dendrites of the $\alpha$ motor neurons.

Atropine has been shown to protect against some of the effects of toxic nerve gases (organophosphorus compounds which inhibit AChE) which have been employed as chemical warfare agents. These compounds are known to affect voluntary movements in the peripheral nervous system (and thus would not be affected by atropine) and can be protected against by administration of oximes. However, some central effects of the organophosphorus compounds can be protected against with atropine (and not by oximes since they cross the blood-brain barrier poorly), indicating the involvement of muscarinic cholinergic receptors (Wills, 1963, 1970; Koelle, 1970; Brimblecombe, 1974). Muscarinic receptors in the cortex, hippocampus, amygdala, and other areas (Kuhar and Yamamura, 1976; Rotter et al., 1979a) could explain the reversal by atropine of the confusion, convulsions, and other behavioral effects of organophosphorus compound poisoning. The major cause of death from this type of poisoning, however, results from respiratory failure which includes an atropine-reversible inhibition of the "respiratory centers" in the central nervous system. Our present localizations of muscarinic receptors in several nuclei in the brainstem known to influence respiration may account for this protective property of atropine. These nuclei include the: parabrachial nuclei (Bertrand and Hugelin, 1971), medullary and pontine reticular formations (Waldron, 1970; Hugelin, 1977), nucleus ambiguus (Batsel, 1964; Merrill, 1970), and the nucleus parasolitarius (von Euler et al., 1973).

Motion sickness is thought to result from overstimulation of the membranous labyrinth of the inner ear and anticholinergics are well known for their anti-motion sickness properties (Wood and Graybiel, 1973) which could be mediated through inhibition in the area of the vestibular nuclei. It may be important to note that, of the vestibular nuclear complex, only the medial vestibular nucleus contained high concentrations of autoradiographic grains. A similar observation was made in a previous report from this laboratory where we were able to demonstrate large concentrations of histamine- $\mathrm{H}_{1}$ receptors in the medial vestibular nucleus (Palacios et al., 1980). Antihistaminics are also well known anti-motion sickness agents and it seems likely that both anticholinergics and antihistaminics have their anti-motion sickness properties mediated through separate receptors in the medial vestibular nucleus. The medial vestibular nucleus is significant since it is the only vestibular nucleus known to receive a descending brainstem input, that being from the interstitial nucleus of Cajal. Thus, it seems possible that the ocular manifestations of vertigo and dizziness (nystagmus) somehow involve the medial vestibular nucleus (through a feedback process) since the interstitial nucleus is involved in controlling movements of the eye due to its connections with oculomotor, trochlear, abducens, and other ocular control areas through the medial forebrain bundle (Carpenter et al., 1970). Current trends in the therapy of aviator's motion sickness 
involve the administration of scopolamine (an anticholinergic) and amphetamine (Wood and Graybiel, 1973). The effects of the amphetamine can be blocked with phenoxybenzamine, indicating the involvement of $\alpha$-adrenergic receptors. Immunohistochemical studies and fluorescent histochemical studies have indicated a lack of noradrenergic fibers in the medial vestibular nucleus (Moore and Bloom, 1978). Previous receptor studies have also indicated few, if any, $\alpha$ receptors in the medial vestibular nucleus (Young and Kuhar, 1980). Thus, it would appear that the amphetamine is having its effects at some other locus.

In this communication, we also report the association of muscarinic cholinergic receptors with many parts of the auditory pathway (dorsal and ventral cochlear nuclei, nuclei of the lateral lemniscus, and the inferior colliculus). A previous report from our laboratory also indicated a correlation between these nuclei and the presence of histamine receptors (Palacios et al, 1980). However, there is one notable exception, that is the superior olive contains a high concentration of histamine receptors with few, if any, muscarinic cholinergic receptors. In the auditory system, it would appear again that histamine and acetylcholine have the potential to have closely associated affects in the same nuclei, but mediated through separate receptors.

One area of proposed functional cholinergic input is the locus coeruleus where we have observed intermediate to high levels of autoradiographic grains. The locus coeruleus has been shown to have AChE-containing cell bodies (Palkovits and Jacobowitz, 1974) as well as demonstrate a measurable concentration of acetylcholine (ACh) and choline acetyltransferase (CAT) (Cheney et al., 1975). Some cells of this nucleus have been demonstrated to contain both $\mathrm{AChE}$ and catecholamines (Knight, 1970). Presumably, these cells release catecholamines at their terminals and contain AChE for postsynaptic degradation of $\mathrm{ACh}$ released from afferent fibers. Microiontophoretic application of $\mathrm{ACh}$ onto cells in the locus coeruleus causes them to fire more rapidly (Kuhar et al., 1978) and injection of physostigmine and oxotremorine (indicating the presence of functional muscarinic cholinergic receptors) can increase the turnover of tyrosine hydroxylase (a catecholamine biosynthetic enzyme) in the locus coeruleus (Lewander et al., 1975). Since the locus coeruleus is known for its widespread noradrenergic projections throughout the neural axis, it would secm apparent that muscarinic cholinergic inputs may be responsible for controlling some activity in this important catecholamine-distributing nucleus. This type of catecholamine control by cholinergic inputs has been proposed to exist in other regions of the nervous system (Story et al., 1975).

Administration of cholinergic antagonists is known to produce a mild central vagal stimulation. This phenomenon could result from stimulation of muscarinic receptors that we have localized in the nucleus ambiguus and in the nucleus tractus solitarius (nts). The nts is known to influence important cardiovascular centers in the medulla (Doba and Reis, 1974). Thus, muscarinic cholinergic drugs could influence vasomotor functions and cardiac rate in this fashion. Rostral extensions of the nts repre- sent the gustatory nucleus and receive afferents from taste receptors via cranial nerves VII, IX, and X. This area of the nts projects to the parabrachial nuclei which have also been shown to respond to gustatory stimuli (Norgren and Pfaffman, 1975; Perotto and Scott, 1976). We found a high density of muscarinic cholinergic receptors in these nuclei as well, indicating a possible role of cholinergics in the mediation of taste. Other sensory nuclei containing significant concentrations of grains include the superior colliculus (vision), the auditory centers mentioned previously, and the dorsal column nuclei (nucleus gracilis and nucleus cuneatus) which receive tactile information and conscious proprioceptive stimuli from the periphery via the spinal cord. We also demonstrated a high concentration of muscarinic cholinergic receptors in the dorsal horn of the spinal cord. The primary sensory afferents in the dorsal roots of the spinal cord project or send collaterals to the gray matter of the dorsal horn, but these fibers have been shown to contain very little $A C h F$ and to be low in CAT activity (Feldberg, 1957; Hebb, 1963). Thus, it would appear that the source of acetylcholine which projects to this area must originate centrally and could represent descending cholinergic control of sensory inpul from higher or reflex centers.

We were able to consistently note the occurrence of a small amount of specific autoradiographic grains in white matter areas such as the cerebellar peduncles. This phenomenon was noticed in previous localizations of muscarinic receptors (Rotter et al., 1979a, b) and some of the sites in the corpus callosum have been shown to be high affinity agonist sites (Wamsley et al., 1980). Binding studies have also revealed the presence of specific binding sites in white matter areas (Snyder et al., 1975). These receptors could be in the process of transport and were localized in the severed axons present in the tissue sections or brain homogenates. Receptor transport has been shown to occur for opiate receptors in the vagus nerve (Young et al., 1980) and for cholinergic receptors in the splenic nerve (Laduron, 1980) and vagus nerve (J. K. Wamsley, M. Zarbin, and M. J. Kuhar, unpublished observations).

Autoradiographic localization of muscarinic cholinergic receptors as outlined in this study and elsewhere (Kuhar and Yamamura, 1974, 1975, 1976; Rotter et al., $1979 \mathrm{a}, \mathrm{b})$ and autoradiographic localization of nicotinic cholinergic receptors (Hunt and Schmidt, 1978a, b) should prove to be a useful adjunct to other cholinergic markers in attempting to map cholinergic pathways in the central nervous system.

\section{References}

Batsel, H. L. (1964) Localization of bulbar respiratory center by microelectrode sounding. Exp. Neurol. 9: 410-426.

Bertrand, F., and A. Hugelin (1971) Respiratory synchronizing function of nucleus parabrachialis medialis: Pneumotaxic mechanisms. J. Neurophysiol. 34: 189-207.

Birdsall, N. J. M., A. S. V. Burgen, and E. C. Hulme (1978) The binding of agonists to brain muscarinic receptors. Mol. Pharmacol. 14: 723-736.

Brimblecombe, R. W. (1974) Anticholinesterase agents. In Drug Actions on Central Cholinergic Systems, pp. 63-132, University Park Press, Baltimore.

Carpenter, M. B., J. W. Harbinson, and P. Peter (1970) Acces- 
sory oculomotor nuclei in the monkey: Projections and effects of discrete lesions. J. Comp. Neurol. 140: 131-154.

Cheney, D. L., H. F. LeFeure, and G. Racagni (1975) Choline acetyltransferase activity and mass fragmentographic measurement of acetylcholine in specific nuclei and tracts of rat brain. Neuropharmacology 14: 801-809.

DeFeudis, F. V. (1974) Central Cholinergic Systems and Behavior, Academic Press, New York.

Doba, N., and D. J. Reis (1974) Role of central and peripheral adrenergic mechanisms in neurogenic hypertension produced by brainstem lesions in rats. Circ. Res. 34: 293-301.

Eng, L. F., C. T. Uyeda, L. P. Chao, and F. Wolfgram (1974) Antibody to bovine choline acetyltransferase and immunofluorescent localization of the enzyme in neurons. Nature 250: 243-245.

Feldberg, W. (1957) Acetylcholine. In Metabolism of the Nervous System, D. Richter, ed., pp. 493-509, Pergamon Press, London.

Fonnum, F. (1975) Review of recent progress in the synthesis, storage and release of acetylcholine. In Cholinergic Mechanisms, P. G. Waser, ed., pp. 145-159, Raven Press, New York.

Hanley, M. R., and L. L. Iversen (1978) Muscarinic cholinergic receptors in rat corpus striatum and regulation of guanosine cyclic 3',5'-monophosphate. Mol. Pharmacol. 14: 246-255.

Hebb, C. O. (1963) Formation, storage and liberation of acetylcholine. Handb. Exp. Pharmacol. 15: 55-88.

Hebb, C. O. (1970) CNS at the cellular level: Identity of transmitter agents. Annu. Rev. Physiol. 32: 165-192.

Hebb, C. O. (1972) Biosynthesis of acetylcholine in nervous tissue. Pharmacol. Rev. 52: 918-947.

Hugelin, A. (1977) Anatomical organization of bulbopontine respiratory oscillators. Fed. Proc. 36: 2390-2394.

Hulme, E. C., N. J. M. Birdsall, A. S. V. Burgen, and P. Mehta (1978) The binding of antagonists to brain muscarinic receptors. Mol. Pharmacol. 14: 737-750.

Hunt, S. P., and J. Schmidt (1978a) The electron microscopic autoradiographic localization of alpha-bungarotoxin binding sites within the central nervous system of the rat. Brain Res. 142: 152-159.

Hunt, S. P., and J. Schmidt (1978b) Some observations on the binding patterns of alpha-bungarotoxin in the central nervous system of the rat. Brain Res. 157: 213-232.

Kimura, H., P. L. McGeer, F. Peng, and E. G. McGeer (1980) Choline acetyltransferase containing neurons in rodent brain demonstrated by immunohistochemistry. Science 208: 10571059.

Knight, D. P. (1970) Histochemical demonstration of catecholamines and acetylcholinesterase in the same cell bodies in the locus coeruleus (rat hindbrain). Proc. R. Microscop. Soc. 6: $26-27$.

Koelle, G. B. (1970) Anticholinesterase agents. In The Pharmacological Basis of Therapeutics. L. S. Goodman and A. Gilman, eds., pp. 445-466, Macmillan, New York.

Konig, J. F. R., and R. A. Klippel (1963) The Rat Brain: A Stereotaxic Atlas. R. E. Krieger Publishing Co., Huntington, New York.

Krnjevic, K. (1969) Central cholinergic pathways. Fed. Proc. 28: $113-120$.

Krnjevic, K. (1974) Chemical nature of synaptic transmission in vertebrates. Physiol. Rev. 54: 418-540.

Kuhar, M. J., and H. I. Yamamura (1974) Light autoradiographic localization of cholinergic muscarinic sites in rat brain. Soc. Neurosci. Abstr. 4: 294.

Kuhar, M. J., and H. I. Yamamura (1975) Light autoradiographic localization of cholinergic muscarinic receptors in rat brain by specific binding of a potent antagonist. Nature 253: 560-561.
Kuhar, M. J., and H. I. Yamamura (1976) Localization of cholinergic muscarinic receptors in rat brain by light microscopic radioautography. Brain Res. 110: 229-243.

Kuhar, M. J., V. H. Sethy, R. H. Roth, and G. K. Aghajanian (1973) Choline: Selective accumulation by central cholinergic neurons. J. Neurochem. 20: 581-593.

Kuhar, M. J., R. N. DeHaven, H. I. Yamamura, H. Rommelspacher, and J. R. Simon (1975) Further evidence for cholinergic habenulo-interpeduncular neurons: Pharmacologic and functional characteristics. Brain Res. 97: 265-276.

Kuhar, M. J., S. F. Atweh, and S. J. Bird (1978) Studies of cholinergic-monoaminergic interactions in rat brain. In Cholinergic-Monoaminergic Interactions in the Brain. L. L. Butcher, ed., pp. 211-227, Academic Press, New York.

Kuhar, M. J., N. Taylor, N. Birdsall, and E. Hulme (1979) Electron microscopic localization of cholinergic muscarinic receptors in rat brain. Soc. Neurosci. Abstr. 9: 2008.

Laduron, P. (1980) Dopamine and muscarinic receptors: In vivo identification, axonal transport and solubilization. In Psychopharmacology and Biochemistry of Neurotransmitter Receptors. R. W. Olsen and H. I. Yamamura, eds., Raven Press, New York, in press.

Lewander, T., 'T. H. Joh, and D. J. Reis (1975) Prolonged activation of tyrosine hydroxylase in noradrenergic neurons of rat brain by cholinergic stimulation. Nature 258: 440-441.

Lewis, P. R., and C. C. D. Shute (1967) The cholinergic limbic system: Projections to hippocampal formation, medial cortex, nuclei of the ascending cholinergic reticular system, and the subfornical organ and supra-optic crest. Brain 90: 521-540.

Lewis, P. R., C. C. D. Shute, and A. Silver (1967) Confirmation from choline acetylase of cholinergic innervation to the rat hippocampus. J. Physiol. (Lond.) 191: 215-224.

McGeer, E. G., J. A. Wada, A. Terao, and E. Jung (1969) Amine synthesis in various brain regions with caudate or septal lesions. Exp. Neurol. 24: 277-284.

McGeer, P. L., E. G. McGeer, V. K. Singh, and W. H. Chase (1974) Choline acetyltransferase in the central nervous system by immunohistochemistry. Brain Res. 81: 373-379.

Merrill, E. G. (1970) The lateral respiratory neurons of the medulla: Their associations with nucleus ambiguus, nucleus retroambigualis, the spinal accessory nucleus and the spinal cord. Brain Res. 24: 11-28.

Moore, R. Y., and F. E. Bloom (1978) Central catecholamine neuron systems: Anatomy and physiology of the dopamine systems. Annu. Rev. Neurosci. 1: 129-169.

Norgren, R., and C. Pfaffman (1975) The pontine taste area in the rat. Brain Res. 91: 99-117.

Osen, K. K. (1969) Cytoarchitecture of the cochlear nuclei of the cat. J. Comp. Neurol. 136: 453-484.

Palacios, J. M., J. K. Wamsley, and M. J. Kuhar (1980) The distribution of histamine $\mathrm{H} 1$-receptors in the rat brain: An autoradiographic study. Neuroscience, in press.

Palkovits, M., and D. M. Jacobowitz (1974) Topographic atlas of catecholamine and acetylcholinesterase-containing neurons in the rat brain. J. Comp. Neurol. 157: 29-42.

Perotto, R., and T. Scott (1976) Gustatory neural coding in the pons. Brain Res. 110: 283-300.

Phillis, J. W. (1970) Pharmacological studies on neurons in the brain and spinal cord. Part I. Cholinergic mechanisms. In The Pharmacology of Synapses, pp. 149-185, Pergamon Press, Elmsford, New York.

Rasmussen, G. L. (1967) Afferent connections of the cochlear nucleus. In Sensorineural Hearing Processes and Disorders, A. B. Graham, ed., pp. 61-75, Little, Brown and Co., Boston. Rotter, A., N. J. M. Birdsall, A. S. V. Burgen, P. M. Field, E. C. Hulme, and G. Raisman (1979a) Muscarinic receptors in the central nervous system of the rat. I. Technique for autoradi- 
ographic localization of the binding of ${ }^{3} \mathrm{H}$-propylbenzilylcholine mustard and its distribution in the forebrain. Brain Res. Rev. 1: 141-165.

Rotter, A., N. J. M. Birdsall, P. M. Field, and G. Raisman (1979b) Muscarinic receptor in the central nervous system of the rat. II. Distribution of binding of ${ }^{3} \mathrm{H}$-propylbenzilylcholine mustard in the midbrain and hindbrain. Brain Res. Rev. 1: 167-183.

Shute, C. C. D., and P. R. Lewis (1963) Cholinesterase-containing systems of the brain of the rat. Nature 199: 1160-1164.

Shute, C. C. D., and P. R. Lewis (1965) Cholinesterase-containing pathways of the hindbrain: Afferent cerebellar and centrifugal cochlear fibers. Nature 205: 242-246.

Shute, C. C. D., and P. R. Lewis (1967) The ascending cholinergic reticular system. Brain 90: 497-519.

Snyder, S. H., K. J. Chang, M. J. Kuhar, and H. I. Yamamura (1975) Biochemical identification of the mammalian muscarinic cholinergic receptor. Fed. Proc. 34: 1915-1921.

Story, D. F., G. S. Allen, A. B. Glover, W. Hope, M. W. McCulloch, M. J. Rand, and C. Sarantos (1975) Modulation of adrenergic transmission by acetylcholine. Clin. Exp. Pharmacol. Physiol. (Suppl.) 2: 27-33.

von Euler, C., J. N. Hayward, I. Morttila, and R. J. Wyman (1973) Respiratory neurons of the ventrolateral nucleus of the solitary tract of cat: Vagal input, spinal connections and morphological identification. Brain Res. 61: 1-22.

Waldron, I. (1970) Activity patterns in respiratory muscles and in respiratory neurons of the rostral medulla of the cat. J. Physiol. (Lond.) 208: 373-383.
Wamsley, J. K., M. Zarbin, N. Birdsall, and M. J. Kuhar (1980) Muscarinic cholinergic receptors: Autoradiographic localization of high and low affinity agonist hinding sites. Brain Res. 200: $1-12$.

Wills, J. H. (1963) Pharmacological antagonists of the anticholinesterase agents. In Handbuch der Experimentellen Pharmakologie. Cholinesterases and Anticholinesterase Agents, G. B. Koelle, ed., pp. 881-920, Springer-Verlag, Berlin.

Wills, J. H. (1970) Anticholinesterase agents. In International Encyclopedia of Pharmacology and Therapeutics, A. G. Karczmar, ed., pp. 357-470, Pergamon Press, Oxford.

Wood, C. D., and A. Graybiel (1973) The antimotion sickness drugs. Otolaryngol. Clin. N. Am. 6: 301-313.

Yamamura, H. I., and S. H. Snyder (1974) Muscarinic cholinergic binding in rat brain. Proc. Natl. Acad. Sci. U. S. A. 184: 1725-1729.

Yamamura, H. I., G. Wastek, K. J. Chang, and S. H. Snyder (1976) Cholinergic receptors in the mammalian central nervous system. Proc. West. Pharmacol. Soc. 19: 13-18.

Young, W. S., III, and M. J. Kuhar (1979) A new method for receptor autoradiography: ${ }^{3} \mathrm{H}$-Opioid receptor labeling in mounted tissue sections. Brain Res. 179: 255-270.

Young, W. S., III, and M. J. Kuhar (1980) Noradrenergic alpha1 and alpha-2 receptors: Light microscopic autoradiographic localization. Proc. Natl. Acad. Sci. U. S. A. 77: 1696-1700.

Young, W. S., III, J. K. Wamsley, M. A. Zarbin, and M. J. Kuhar (1980) Opiate recepiors undergo axonal flow. Science 210: $76-78$ 